\title{
KEABSAHAN AKTA RISALAH LELANG SEBAGAI AKTA OTENTIK DALAM PELAKSANAAN LELANG ELEKTRONIK OLEH KANTOR PELAYANAN KEKAYAAN NEGARA DAN LELANG
}

\author{
Ahnia Septya Karina, Sukarmi, Endang Sri Kawuryan \\ Magister Kenotariatan Fakultas Hukum Universitas Brawijaya \\ Email: ahniaseptyakarina@gmail.com
}

\section{Abstract}

Currently, auction can be done through internet media a.k.a. e-auction. E-auction sells the goods by offering written prices without the presence of participants conducted through an internet-based auction application. This internet-based auction is similar with conventional one. The difference is in case of face-to-face which will affect the originality of Auction Treatise. Treatise is the official report of auction issued by Auction Officer. This paper aims at analyzing the validity of treatise as an authentic document in e-auction. This is a normative juridical writing by analyzing the validity of e-auction treatise reviewed with legislation related to internet-based auction. The results indicate that the treatise in e-auction is authentic since it follows the principles written in Article 1868 of the Civil Code. However, in PMKNumber 90/PMK.06/2016 and Vendu Reglement concerning the recitation of the chief of Auction Treatise can be done using Lex Specialis Derogat Legi Generalis principles. The e-auction treatise also has valid proof as long as there is no lawsuit filing.

Saat ini, lelang dapat dilakukan melalui media internet atau e-auction. E-auction adalah penjualan barang dengan penawaran harga secara tertulis tanpa kehadiran peserta lelang yang dilakukan melalui aplikasi lelang berbasis internet. Lelang berbasis internet ini sama seperti pelaksanaan lelang konvensional. Perbedaany terletak dalam hal tatap muka yang nantinya akan berpengarub terbadap keotentikan Risalah Lelang. Risalah Lelang adalah berita acara pelaksanaan lelang yang dibuat oleh Pejabat Lelang. Makalah ini menganalisis keabsahan akta Risalah Lelang sebagai akta otentik dalam pelaksanaan lelang elektronik.

Penulisan ini adalah yuridis normatif dengan menganalisis keabsahan Risalab Lelang elektronik yang dikaji dengan peraturan perundang-undangan yang berkaitan dengan lelang melalui internet. Hasil menunjukkan bahwa Risalah Lelang dalam lelang internet 
merupakan akta otentik karena telah memenubi unsur-unsur dalam Pasal $1868 \mathrm{KUH}$ Perdata. Namun dalam PMK Nomor 90/PMK.06/2016 dan Vendu Reglement tentang pembacaan Kepala Risalah Lelang tersebut dapat terselesaikan dengan asas Lex Specialis Derogat Legi Generalis. Risalah Lelang dalam lelang melalui media internetjuga memiliki kekuatan pembuktian sempurna sepanjang tidak ada yang melakukan gugatan.

Keywords: auction treatise, authentic document, e-auction

\section{Pendahuluan}

Di era globalisasi, perkembangan teknologi dan informasi berjalan sangat pesat dan telah membawa berbagai dampak dalam kehidupan masyarakat. Internet digunakan hampir seluruh masyarakat di muka bumi ini dan merupakan jaringan informasi yang terbesar di dunia. Terdapat berbagai kemudahan yang ditawarkan oleh perkembangan teknologi dan informasi tersebut adalah dapat membuat hubungan antar manusia berlangsung secara cepat dan mudah.

Saat ini, banyak masyarakat yang memanfaatkan media internet sebagai media untuk berdagang yang disebut dengan Electronic Commercer atau biasa disebut dengan $E$-Commerce. Perkembangan perdagangan melalui jaringan internet ini merupakan salah satu inovasi baru dalam dunia perdagangan. Perdagangan yang dilakukan melalui media internet dilakukan agar dapat memperluas jaringan untuk konsumen. Salah satu bentuk perdagangan yang dilakukan melalui media internet adalah jual beli yang dilakukan dengan cara lelang.

Menurut Pasal 1 ayat (1) Peraturan Menteri Keuangan Nomor 27/ PMK.06/2016 (Berita Negara Republik Indonesia Tahun 2016 Nomor 270), Lelang adalah Penjualan yang terbuka untuk umum dengan penawaran harga secara tertulis dan/atau lisan semakin meningkat atau menurun untuk mencapai harga tertinggi, yang didahului dengan Pengumuman lelang. ${ }^{1}$

Penjualan yang dilakukan secara lelang wajib dilaksanakan oleh atau dihadapan Pejabat Lelang. Pejabat Lelang merupakan Pejabat umum yang telah diberi wewenang khusus oleh Menteri Keuangan untuk melaksanakan lelang berdasarkan peraturan perundang-undangan. ${ }^{2}$ Pejabat Lelang juga bertugas untuk mempersiapkan dan melaksanakan penyelenggaraan lelang, baik tugas dalam kegiatan persiapan lelang (pra lelang), pelaksanaan lelang, maupun setelah penyelenggaraan lelang (pasca lelang). ${ }^{3}$

1 Penjelasan Pasal 1 ayat (1) Peraturan Menteri Keuangan Republik Indonesia Nomor 27/PMK.06/2016 tentang Petunjuk Pelaksanaan Lelang.

2 Rachmadi Usman, Hukum Lelang (Jakarta: Sinar Grafika, 2015), h. 34.

3 Rachmadi Usman, Hukum Lelang, h. 38. 
Pejabat Lelang terdiri atas Pejabat Lelang Kelas I dan Pejabat Lelang Kelas II. Pejabat Lelang Kelas I berwenang untuk melaksanakan lelang eksekusi, non eksekusi wajib dan non eksekusi sukarela. Sedangkan Pejabat Lelang Kelas II berwenang untuk melaksanakan lelang non eksekusi sukarela.

Namun sejak adanya perkembangan perdagangan yang dilakukan melalui internet ini, menyebabkan banyaknya pelaku usaha yang beralih dari lelang biasa (konvensional) ke lelang yang melalui media internet. Lelang yang dilakukan melalui media internet dalam Bahasa asing disebut vendutie (Bld) - auction (Ing) dan biasa disebut dengan istilah e-auction. ${ }^{4}$

Pengertian lelang melalui internet atau e-auction diatur dalam Pasal 1 angka 1 Peraturan Menteri Keuangan Republik Indonesia Nomor 90/PMK.06/2016, yaitu: "Penjualan barang yang terbuka untuk umum dengan penawaran harga secara tertulis tanpa kehadiran peserta lelang untuk mencapai harga tertinggi yang dilakukan melalui aplikasi lelang berbasis internet".

Penyelenggaraan e-auction dilakukan oleh Kantor Pelayanan Kekayaan Negara dan Lelang (KPKNL) dan Balai Lelang. Lelang melalui internet atau e-auction ini dinilai sangat efektif dan efisien serta dapat dilakukan dimana saja bagi para peserta. E-auction tersebut juga tidak perlu lagi dilakukan secara bertatap muka pada hari, tempat, dan waktu pelaksanaan yang telah ditentukan sebelumnya.

Akan tetapi menurut penulis, selain adanya keuntungan yang ditawarkan, terdapat pula beberapa permasalahan yaitu transaksi seperti ini belum mampu memberikan rasa aman, kepastian hukum, serta keadilan, karena para pihak dalam pelaksanaan lelange-auction tersebut tidak dapat bertemu secara langsung sebagaimana yang terjadi pada lelang konvensional sehingga tidak dapat menjamin mengenai keaslian data dan kondisi benda yang ditawarkan oleh penjual lelang melalui media internet.

Lelang juga merupakan suatu lembaga hukum yang harus memuat aspekaspek filosofis yaitu dapat menjamin kepastian hukum, keadilan serta kemanfaatan. Dalam aspek kepastian hukum, setiap pelaksanaan lelang wajib diterbitkan Risalah Lelang.

Pengertian Risalah Lelang tercantum dalam Pasal 1 angka 35 Peraturan Menteri Keuangan Nomor 27/PMK.06/2016 (Berita Negara Republik Indonesia Tahun 2016 Nomor 270), yaitu berita acara pelaksanaan lelang yang dibuat

4 Yan Pramadya Puspa, Kamus Hukum Edisi Lengkap Bahasa Indonesia Inggris (Semarang: Aneka Ilmu, 1977), h. 959.

5 Penjelasan Pasal 1 angka 1 Peraturan Menteri Keuangan Republik Indonesia Nomor 90/PMK.06/2016 tentang Pedoman Pelaksanaan Lelang Dengan Penawaran Secara Tertulis Tanpa Kehadiran Peserta Lelang Melalui Internet. 
oleh Pejabat Lelang yang merupakan akta otentik dan mempunyai pembuktian sempurna. ${ }^{6}$

Risalah Lelang merupakan akta otentik yang dapat digunakan oleh pihak penjual sebagai bukti telah dilaksanakannya penjualan sesuai prosedur lelang, sedangkan bagi pembeli, Risalah Lelang digunakan sebagai bukti pembelian yang digunakan untuk balik nama. Risalah Lelang merupakan akta otentik sebagaimana menurut ketentuan dalam Pasal 1868 Kitab UndangUndang Hukum Perdata, yang menyatakan bahwa akta otentik adalah suatu akta yang didalam bentuk yang ditentukan oleh undang-undang, dibuat oleh atau dihadapan pegawai-pegawai umum yang berkuasa untuk itu di tempatkan di mana akta itu dibuatnya.

Dalam pelaksanaan lelang melalui media internet atau e-auction, pada bagian Kepala Risalah Lelang tidak dibacakan oleh Pejabat Lelang berbeda halnya dengan lelang yang dilakukan secara konvensional, bagian Kepala Risalah Lelang ini hanya ditayangkan pada aplikasi lelang elektronik tanpa adanya pembacaan oleh Pejabat Lelang. Hal tersebut tercantum dalam Pasal 13 ayat (1) Peraturan Menteri Keuangan Republik Indonesia Nomor 90/PMK.06/2016 yang menyatakan bahwa pelaksanaan lelang melalui internet dimulai dengan penayangan Kepala Risalah Lelang oleh Pejabat Lelang. ${ }^{8}$

Namun penayangan Kepala Risalah Lelang melalui media internet tersebut bertentangan dengan ketentuan pada Vendu Reglement, dalam Vendu Reglement menyatakan bahwa Risalah Lelang harus dibacakan oleh Pejabat Lelang hal ini tercantum dalam Pasal 37 Vendu Reglement yang menyatakan bahwa pada permulaan penjualan juga dalam melanjutkan penjualan yang berhenti dipertengahan pelelangan, bagian pokok berita acara harus dibacakan dengan suara keras oleh atau atas nama juru lelang kepada hadirin Hal pembacaan ini harus disebut dalam berita acara. ${ }^{9}$

Pembacaan Risalah Lelang oleh Pejabat Lelang merupakan kewajiban dalam pembuatan akta otentik, namun apabila hal tersebut tidak dilakukan dalam pelaksanaan lelang melalui media internet maka akta tersebut akan diragukan keontentisitasnya. Permasalahan keabsahan atau keontentikan terhadap Risalah 6 Penjelasan Pasal 1 angka 35 Peraturan Menteri Keuangan Republik Indonesia Nomor 27/ PMK.06/2016 tentang Petunjuk Pelaksanaan Lelang.

7 Penjelasan Pasal 1868 Staatsblaad Nomor 23 Tahun 1847 tentang Burgerlijk Wetboek Voor Indonesie (selanjutnya disebut KUH Perdata).

8 Penjelasan Pasal 13 ayat (1) Peraturan Menteri Keuangan Republik Indonesia Nomor 90/PMK.06/2016 tentang Pedoman Pelaksanaan Lelang Dengan Penawaran Secara Tertulis Tanpa Kehadiran Peserta Lelang Melalui Internet.

9 Penjelasan Pasal 37 Vendu Reglement tentang Peraturan Lelang. 
Lelang dalam pelaksanaan lelang elektronik tersebut terdapat dalam ketentuan Pasal 1868 Kitab Undang-Undang Hukum Perdata.

Hal tersebut disebabkan karena pada pelaksanaan e-auction dalam prakteknya menimbulkan beberapa pertanyaan, khususnya bagi keabsahan Risalah Lelang karena apakah Risalah Lelang yang dibuat melalui lelang elektronik atau e-auction dapat dikategorikan sebagai akta yang bersifat otentik apabila ditinjau dari keontentikan suatu akta, karena keontentikan akta harus didasarkan pada 3 (tiga) nilai pembuktian, yaitu: (1) Nilai lahiriah (Uitwendige Bewijskracht). Kemampuan lahiriah akta notaris merupakan akta itu sendiri untuk membuktikan keabsahannya sebagai akta otentik. ${ }^{10}$ (2) Nilai formal (Formele Bewijskracht). Kemampuan unuk membuktikan kebenaran mengenai hal-hal yang termuat dalam akta. Kebenaran tersebut meliputi apa yang disaksikan, dilihat, didengar. Hal-hal yang harus terjamin dalam arti formal yaitu: Kebenaran tanggal akta pada saat dibuat, Kebenaran yang terdapat pada akta itu, Kebenaran Identitas dari orangorang yang hadir, Kebenaran tempat di mana akta dibuat sesuai dengan wilayah kerja. ${ }^{11}$ (3) Nilai materiil (Materiele Bewijskracht). Kebenaran tentang materi suatu akta bahwa apa yang tersebut dalam akta merupakan pembuktian yang sah terhadap pihak-pihak yang membuat akta atau yang mendapatkan hak yang berlaku untuk umum, kecuali ada pembuktian sebaliknya. ${ }^{12}$

Permasalahan utama dalam penilaian keontentikan Risalah Lelang dalam e-auction tersebut terkait pada nilai pembuktian formal, dimana akta Risalah Lelang yang dibuat melalui $e$-auction tersebut secara formal harus dapat dibuktikan tentang kebenaran dan kepastian tentang hari, tanggal, bulan, tahun, pukul (waktu), para pihak, paraf dan tanda tangan para pihak, serta membuktikan apa yang dilihat, disaksikan, dan didengar oleh para pihak.

Permasalahan dalam hal ini, masih akan ada masalah dalam hal pembuktian apabila dikemudian hari terdapat sengketa di Pengadilan terutama pada lelang yang diselenggarakan oleh Kantor Pelayanan Kekayaan Negara dan Lelang (KPKNL) yang bertugas untuk melaksanakan lelang eksekusi, lelang non eksekusi wajib, dan lelang non eksekusi sukarela karena memiliki resiko yang lebih banyak. Terutama menyangkut mengenai tentang bagaimana kekuatan pembuktian Risalah Lelang melalui media intenet ini, nantinya tentu akan dibandingkan dengan kekuatan pembuktian akta otentik karena masyarakat menginginkan kepastian hukum yang sempurna.

10 Habib Adjie, Menjalin Pemikiran - Pendapat Tentang Kenotariatan (Kumpulan Tulisan) (Bandung: Citra Aditya Bakti, 2013), h. 125.

11 Salim HS, Teknik Pembuatan Akta Satu (Konsep teoritis, Kewenangan Notaris, bentuk dan Minuta Akta) (Jakarta: PT. Raja Grafindo Persada, 2015), h. 30.

12 Habib Adjie, Menjalin Pemikiran, h. 127. 
Berdasarkan uraian tersebut diatas, maka penulis tertarik untuk mengkaji lebih dalam permasalahan mengenai Keabsahan Akta Risalah Lelang Sebagai Akta Otentik Dalam Pelaksanaan Lelang Elektronik Oleh Kantor Pelayanan Kekayaan Negara dan Lelang (KPKNL).

\section{Metode Penelitian}

Penelitian ini menggunakan jenis penelitian yuridis normatif yang mengkaji dan menganalisa peraturan perundang-undangan yang berlaku dan diterapkan terhadap suatu permasalahan hukum tertentu dalam hal ini dilakukan dengan cara menganalisis peraturan perundang-undangan yang berkaitan dengan lelang melalui media internet. Pendekatan penelitian yang digunakan yaitu pendekatan perundang-undangan dan pendekatan perbandingan. Pendekatan Perundangundangan dilakukan dengan cara menelaah peraturan-peraturan yang terkait dengan permasalahan yang diangkat, serta berguna untuk mencari dasar hukum dan mempelajari konsistensi kesesuaian ketentuan-ketentuan yang ada dalam undang-undang atau suatu undang-undang dengan undang-undang yang lain. ${ }^{13}$ Pendekatan Perbandingan yaitu kegiatan untuk membandingkan hukum suatu negara dengan hukum negara lain atau hukum dari suatu waktu tertentu dengan hukum dari waktu yang lain. ${ }^{14}$ Bahan hukum dalam tulisan ini menggunakan bahan hukum primer dan bahan hukum sekunder.

\section{Pembahasan}

\section{Keontentikan Risalah Lelang Melalui Internet}

Lelang melalui media internet lelang melalui internet atau e-auction diatur dalam Pasal 1 angka 1 Peraturan Menteri Keuangan Republik Indonesia Nomor 90/PMK.06/2016, lelang melalui internet adalah: Penjualan barang yang terbuka untuk umum dengan penawaran harga secara tertulis tanpa kehadiran peserta lelang untuk mencapai harga tertinggi yang dilakukan melalui aplikasi lelang berbasis internet. 15

Lelang (auction) menurut pengertian transaksi muamalah kontemporer

13 Bahder Johan Nasution, Metode Penelitian Ilmu Hukum (Bandung: Penerbit Mandar Maju, 2008), h. 137.

14 Peter Mahmud Marzuki, Penelitian Hukum Edisi Revisi (Jakarta: Prenadamedia Group, 2005), h. 173.

15 Penjelasan Pasal 1 angka 1 Peraturan Menteri Keuangan Republik Indonesia Nomor 90/PMK.06/2016 tentang Pedoman Pelaksanaan Lelang Dengan Penawaran Secara Tertulis Tanpa Kehadiran Peserta Lelang Melalui Internet. 
dikenal sebagai bentuk penjualan barang di depan umum kepada penawar tertinggi. Lelang dapat berupa penawaran barang tertentu kepada penawar yang pada mulanya membuka lelang dengan harga rendah, kemudian semakin naik sampai akhirnya diberikan kepada calon pembeli dengan harga tertinggi, sebagaimana lelang ala Belanda (Dutch Auction) dan disebut (lelang naik). Kitab-kitab fikih atau hadist, jual beli lelang disebut dengan istilah Bai' Al Muzayadah. Lelang dalam muamalat adalah transaksi dalam Islam yang merupakan penjualan di depan umum dengan sistem tawar menawar tertinggi. Lelang adalah jual beli yang diperbolehkan di dalam Islam dengan syarat-syarat yang ditentukan dan disesuaikan dengan hukum Islam sesuai aturan $\mathrm{Al}$ Quran, $\mathrm{Al}$ Hadist, dan Ijma; ulama dan aturan hukum syariat. ${ }^{16}$

Menurut istilah dalam Islam, lelang (Al Muzayadah), secara bahasa (lughah-etimologi) adalah Berlomba-lomba dalam menambah harga barang dagangan yang dipamerkan untuk dijual. Adapun makna lelang secara terminologi adalah Menyerukan barang dagangan dan manusia satu sama lain saling menambahkan harga terhadap barang itu sampai berhenti penambahan itu pada penawar tertentu lalu dialah yang mengambilnya. Jual beli lelang (Al Muzayadah), kadang dinamakan $A d$ Dalaalah, atau Al Munaadah, atau bai'u man yaziid, atau menurut istilah ahli fiqih, Bai'ul Fuqaraa.

Ketentuan Pasal 1 angka 4 Undang-Undang Nomor 19 Tahun 2016 tentang Perubahan Atas Undang-Undang Nomor 11 Tahun 2008 (Lembaran Negara Nomor 58, Tambahan Lembaran Negara Nomor 4843) tentang Informasi Dan Transaksi Elektronik memberikan pengertian mengenai Dokumen Elektronik adalah setiap Informasi Elektronik yang dibuat, diteruskan, dikirimkan, diterima, atau disimpan dalam bentuk analog, digital, elektromagnetik, optikal, atau sejenisnya, yang dapat dilihat, ditampilkan, dan/atau didengar melalui Komputer atau Sistem Elektronik, termasuk tetapi tidak terbatas pada tulisan, suara, gambar, peta, rancangan, foto atau sejenisnya, huruf, tanda, angka, Kode Akses, simbol atau perforasi yang memiliki makna atau arti atau dapat dipahami oleh orang yang mampu yaitu untuk membuat Risalah Lelag sebagaimana tercantum dalam Pasal memahaminya. ${ }^{17}$ Berdasarkan ketentuan tersebut, maka definisi dan mekanisme penawaran lelang telah mendapat perluasan khususnya dari sudut media yang digunakan untuk menyelenggarakan lelang. Lelang bukan lagi hanya penjualan barang yang terbuka untuk umum secara langsung, melainkan juga secara tidak langsung melalui media elektronik. ${ }^{18}$

16 Satya Haprabu, Burhanudin Harahap, Penjualan Lelang Barang Jaminan Hak Tanggungan Menurut Prespektif Hukum Islam, Jurnal Reportorium, Vol. IV, No.1 Januari-Juni Tahun 2017, h. 59.

17 Penjelasan Pasal 1 angka 4 Undang-Undang Nomor 19 Tahun 2016 tentang tentang Perubahan Atas Undang-Undang Nomor 11 Tahun 2008 tentang Informasi dan Transaksi Elektronik.

18 Begiyama Fahmi Zaki, Kepastian Hukum Dalam Pelelangan Objek Hak Tanggungan Secara Online, Fiat Justicia Journal of Law, Vol. 2, No. 2 April-June 2016, h. 5. 
Berkaitan dengan kewenangan yang diberikan kepada Pejabat Lelang sebagaimana telah tercantum dalam Pasal 85 ayat (1) Peraturan Menteri Keuangan Nomor 27/PMK.06/2016 (Berita Negara Republik Indonesia Tahun 2016 Nomor 270), dimana Pasal 85 ayat (1) menyatakan bahwa Pejabat Lelang wajib membuat berita acara lelang atau biasa disebut dengan Risalah Lelang.

Risalah lelang menurut Peraturan Menteri Keuangan Nomor 90/PMK.06/2016 merupakan berita acara pelaksanaan lelang yang dibuat oleh Pejabat Lelang. Risalah Lelang ini juga merupakan akta otentik serta mempunyai kekuatan pembuktian yang sempurna. Risalah Lelang yang dihasilkan pada pelaksanaan lelang melalui media internet tersebut juga dikategorikan kedalam dokumen elektronik. Hal tersebut dikarenakan adanya penayangan Kepala Risalah Lelang yang dilakukan sebelum lelang dimulai pada aplikasi lelang. Risalah lelang yang juga merupakan dokumen elektronik tersebut juga harus memenuhi unsur-unsur dalam Pasal 1868 Kitab Undang-Undang Hukum Perdata mengenai akta otentik.

Bentuk dan tata cara pembuatan Risalah lelang sama seperti pembuatan Risalah Lelangyang dilakukan melalui lelang konvensional, akan tetapi perbedaannya terletak dalam hal menghadap dimana selama pelaksanaan lelang konvensional dilakukan dengan cara hadir secara fisik sedangkan pada lelang melalui media internet dilakukan dengan menggunakan alat elektronik.

Sedangkan perbedaan yang lain terletak pada pembacaan Risalah Lelang dan penandatanganan Risalah Lelang. Risalah Lelang dalam lelang konvensional dibacakan oleh Pejabat Lelang kepada peserta lelang, namun berbeda dengan Risalah Lelang dalam lelang melalui media internet, Kepala Risalah Lelang melalui media intenet ini hanya ditanyangkan pada aplikasi lelang yang telah disediakan sebelum pelaksanaan lelang dimulai tanpa adanya pembacaan. Hal tersebut diatur dalam Pasal 13 ayat (1) Peraturan Menteri Keuangan Nomor 90/PMK.06/2016 yang menyatakan bahwa Pelaksanaan Lelang Melalui Internet dimulai dengan penayangan Kepala Risalah Lelang oleh Pejabat Lelang". ${ }^{19}$

Adapun tata cara penayangan Risalah Lelang berdasarkan Pasal 13 ayat (2) PMK Nomor 90/PMK.06/2016 adalah sebagai berikut: (a) Untuk lelang melalui media internet dengan penawaran tertutup (close bidding), dilakukan sesuai dengan jadwal pembukaan daftar penawaran lelang sebagaimana dicantumkan dalam pengumuman lelang. (b) Untuk lelang melalui media internet dengan

19 Penjelasan Pasal 13 ayat (1) Peraturan Menteri Keuangan Republik Indonesia Nomor 90/PMK.06/2016 tentang Pedoman Pelaksanaan Lelang Dengan Penawaran Secara Tertulis Tanpa Kehadiran Peserta Lelang Melalui Internet. 
penawaranterbuka (close bidding), dilakukan sesuai dengan jadwal pelaksanaan lelang sebagaimana dicantumkan dalam pengumuman lelang." ${ }^{20}$

Namun dalam ketentuan tersebut diatas, bertentangan dengan ketentuan dalam Pasal 37 Vendu Reglement yang merupakan dasar dari peraturan lelang, yaitu Pada permulaan penjualan juga dalam melanjutkan penjualan yang berhenti dipertengahan pelelangan, bagian pokok berita acara harus dibacakan dengan suara keras oleh atau atas nama juru lelang kepada hadirin. Hal pembacaan ini harus disebut dalam berita acara. ${ }^{21}$ Sehingga pembacaan Risalah Lelang merupakan bagian dari verlidjen atau peresmian dari pembacaan akta dan penandatanganan terhadap Risalah Lelang tersebut. Apabila Risalah Lelang tersebut dibuat oleh Pejabat Lelang maka Risalah Lelang tersebut juga harus dibacakan oleh Pejabat Lelang.

Verlidjen merupakan kata kerja yang diambil dari kata verleden yang diartikan sebagai telah dibuat. Kata terakhir ini berasal dari bahasa Belanda kuno dan tidak dipakai lagi dalam bahasa sehari-hari dan hanya digunakan dalam bidang hukum. ${ }^{22}$

Pembacaan akta tersebut bertujuan agar peserta lelang mempunyai jaminan apabila mereka telah menandatangani apa yang mereka dengar sebelumnya (pembacaan oleh Pejabat Lelang) agar memperoleh keyakinan bahwa Risalah Lelang tersebut benar-benar berisikan apa yang dikehendaki oleh peserta lelang.

Apabila pembacaan Risalah Lelang dihubungkan dengan fungsi akta otentik dalam pembuktian, maka dapat dilihat bahwa dalam pembuatan Risalah Lelang pembacaan akta merupakan kewajiban bagi Pejabat Lelang dalam pelaksanaan jabatannya. Sama halnya dalam lelang melalui media imternet pambacaan Kepala Risalah Lelang tersebut seharusnya tetap dibacakan tidak hanya ditanyangkan.

Sehubungan dengan hal tersebut, menurut Tan Thong Kie bahwa pembacaan akta memiliki manfaat, antara lain: ${ }^{23}$ (a) Pada saat peresmian (verlidjen) akta akan berakhir, masih ada kesempatan bagi pejabat untuk memperbaiki kesalahan dalam penulisan kata/kalimat yang sebelumnya tidak tampak karena bisa saja terjadi adanya kesalahan fatal atau yang memalukan. (b) Para penghadap diberi kesempatan untuk mengajukan pertanyaan yang kurang jelas atau kurang dimengerti dari isi akta yang ditulis/dibacakan. (c) Pejabat umum dan para penghadap mempunyai kesempatan pada detik-detik terakhir sebelum akta tersebut selesai ditandatangani oleh para penghadap, para saksi, Pejabat Umum untuk mengadakan pemiiran ulang

20 Penjelasan Pasal 37 Vendu Reglement tentang Peraturan Lelang.

21 Penjelasan Pasal 37 Vendu Reglement tentang Peraturan Lelang.

22 Tan Thong Kie, Serba Serbi Ilmu Kenotariatan, (Bandung: Alumni, 1987), h. 11

23 Tan Thong Kie, Serba Serbi Ilmu Kenotariatan, h. 12. 
mengenai isi akta, bertanya, maupun mengubah isi akta. Adapun pelanggaran yang dilakukan jika pembacaan Risalah Lelang tersebut tidak dilakukan oleh Pejabat Lelang, maka Risalah Lelang tersebut akan mempunyai kekuatan pembuktian sebagaimana akta dibawah tangan atau dengan kata lain Risalah Lelang tersebut kehilangan keontentisitasnya.

Namun jika dihubungkan dengan ketentuan dalam Pasal 1868 Kitab UndangUndang Hukum Perdata menyatakan bahwa: Suatu akta yang didalam bentuk yang ditentukan oleh undang-undang, dibuat oleh atau dihadapan pegawai-pegawai umum yang berkuasa untuk itu di tempatkan di mana akta itu dibuatnya. ${ }^{24}$

Adapun unsur-unsur dalam Pasal 1868 Kitab Undang-Undang Hukum Perdata adalah:

1. Bentuk aktanya dibuat sesuai dengan yang ditentukan oleh Undang Undang (wettelijkje vorm)

Pembuatan Risalah Lelang melalui media internet dalam Peraturan Menteri Keuangan Nomor 90/PMK.06/2016 tentang Pedoman Pelaksanaan Lelang dengan Penawaran Secara Tertulis Tanpa Kehadiran Peserta Lelang Melalui Media Internet tidak diatur secara khusus dan hanya mengatur sebatas penayangan Risalah Lelang dan penandatanganan Risalah Lelang.

Pembuatan Risalah Lelang melalui media internet tersebut sama seperti pembuatan Risalah Lelang secara konvensional yang membedakan hanya pada pelaksanaannya saja. Sehingga dalam pembuatan Risalah Lelang melalui media internet tersebut harus menganut pada peraturan pembuatan Risalah Lelang Konvensional seperti Vendu Reglement yang diatur dalam Pasal 37 sampai dengan Pasal 39 dan Peraturan Peraturan Menteri Keuangan Nomor 27/PMK.06/2016 (Berita Negara Republik Indonesia Tahun 2016 Nomor 270) tentang Petunjuk Pelaksanaan Lelang.

Dalam PMK Nomor 27/PMK.06/2016 (Berita Negara Republik Indonesia Tahun 2016 Nomor 270), pada BAB VI mengenai Risalah lelang mengatur susunan dari Risalah Lelang. Pasal 85 ayat (2) Risalah Lelang terdiri atas (a) Bagian Kepala; (b) Bagian Badan; dan (c) Bagian Kaki." ${ }^{25}$ Risalah Lelang dibuat dalam bahasa Indonesia, setiap Risalah lelang diberi nomor urut. Pasal 86 PMK Nomor 27/PMK.06/2016 (Berita Negara Republik Indonesia Tahun 2016 Nomor 270), menerangkan bagian Kepala Risalah Lelang paling sedikit memuat: (a) hari, tanggal, dan jam lelang ditulis dengan huruf dan angka, (b) nama lengkap dan tempat kedudukan Pejabat Lelang, (c) nomor dan tanggal surat keputusan

24 Penjelasan Pasal 1868 Staatsblaad Nomor 23 Tahun 1847 tentang KUH Perdata

25 Penjelasan Pasal 85 ayat (2) Peraturan Menteri Keuangan Republik Indonesia Nomor 27/PMK.06/2016 tentang Petunjuk Pelaksanaan Lelang. 
pengangkatan Pejabat Lelang, (d) nomor dan tanggal surat tugas khusus untuk Pejabat Lelang Kelas, (e) nama lengkap, pekerjaan dan tempat kedudukan atau domisili Penjual, (f). nomor atau tanggal surat permohonan lelang, (g) tempat pelaksanaan lelang, (h) sifat barang yang dilelang dan alasan barang tersebut dilelang, (i) dalam hal objek lelang berupa barang tidak bergerak berupa tanah atau tanah dan bangunan harus disebutkan: 1. status hak atau surat-surat lain yang menjelaskan bukti Kepemilikan, 2. Nomor dan tanggal SKT/SKPT dari Kantor Pertanahan, dan 3. keterangan lain yang membebani, apabila ada, (j) dalam hal objek lelang berupa barang bergerak harus disebutkan jumlah, jenis dan spesifikasi barang; (k) cara Pengumuman Lelang yang telah dilaksanakan oleh Penjual, (l) cara penawaran lelang, dan $(\mathrm{m})$ syarat dan ketentuan lelang. ${ }^{26}$

Kemudian pada bagian Badan Risalah Lelang diatur dalam Pasal 87 PMK Nomor 27/PMK.06/2016 (Berita Negara Republik Indonesia Tahun 2016 Nomor 270) sekurangnya harus memuat: (a) banyaknya penawaran lelang yang masuk dan sah. (b) nama/merek/ jenis/tipe dan jumlah barang yang dilelang. (c) nama, pekerjaan dan alamat Pembeli atas nama sendiri atau sebagai kuasa atas nama badan hukum/badan usaha/ orang lain. (d). bank kreditor sebagai Pembeli untuk orang atau badan hukum atau badan usaha yang akan ditunjuk namanya, dalam hal bank kreditor sebagai Pembeli Lelang. (e) harga lelang dengan angka dan huruf, dan (f) daftar barang yang laku terjual maupun yang ditahan disertai dengan harga, nama, dan alamat Peserta Lelang yang menawar tertinggi". ${ }^{27}$

Sedangkan pada bagian Kaki Risalah Lelang tercantum dalam Pasal 88 PMK Nomor 27/PMK.06/2016 (Berita Negara Republik Indonesia Tahun 2016 Nomor 270): ${ }^{28}$ (a) banyaknya barang yang ditawarkan atau dilelang dengan angka dan huruf, (b) banyaknya barang yang laku atau terjual dengan angka dan huruf, (c) jumlah harga barang yang telah terjual dengan angka dan huruf, (d) jumlah harga barang yang ditahan dengan angka dan huruf, (e) banyaknya dokumen atau suratsurat yang dilampirkan pada Risalah Lelang dengan angka dan huruf, (f) jumlah perubahan yang dilakukan (catatan, tambahan, coretandengan penggantinya) maupun tidak adanya perubahan ditulis dengan angka dan huruf, (g) tanda tangan Pejabat Lelang dan Penjual atau kuasa Penjual, dalam hal lelang barang bergerak atau tanda tangan Pejabat Lelang, Penjual atau kuasa Penjual dan Pembeli atau

26 Penjelasan Pasal 86 Peraturan Menteri Keuangan Republik Indonesia Nomor 27/PMK.06/2016 tentang Petunjuk Pelaksanaan Lelang.

27 Penjelasan Pasal 87 Peraturan Menteri Keuangan Republik Indonesia Nomor 27/PMK.06/2016 tentang Petunjuk Pelaksanaan Lelang.

28 Penjelasan Pasal 88 Peraturan Menteri Keuangan Republik Indonesia Nomor 27/PMK.06/2016 tentang Petunjuk Pelaksanaan Lelang. 
kuasa Pembeli, dalam hal lelang barang tidak bergerak, dan (h) tanda tangan saksisaksi untuk lelang dengan penawaran tanpa kehadiran Peserta Lelang melalui surat elektronik (emai), tromol pos atau internet (closed bidding).

2. Akta tersebut dibuat oleh (door) atau dihadapan (ten overstain) pejabat umum (openbaar ambtenaar)

Dalam ketentuan pada Pasal 1 angka 35 Peraturan Menteri Keuangan Nomor 27/PMK.06/2016 (Berita Negara Republik Indonesia Tahun 2016 Nomor 270) menyatakan bahwa: Risalah Lelang adalah berita acara pelaksanaan lelang yang dibuat oleh Pejabat Lelang yang merupakan akta otentik dan mempunyai kekuatan pembuktian sempurna. ${ }^{29}$

Menurut Pasal 1a Vendu reglement menyatakan bahwa: Tanpa mengurangi ketentuan alinea berikut dalam pasal ini, penjualan dimuka umum tidak boleh dilakukan selain di hadapan juru lelang. ${ }^{30}$ Sedangkan menurut Pasal 35 Vendu Reglement menyatakan bahwa Dari tiap-tiap penjualan umum yang dilakukan oleh juru lelang atau kuasanya, selama penjualan, untuk tiap-tiap hari pelelangan atau pejualan harus dibuat berita acara tersendiri”. ${ }^{31}$

Yang artinya bahwa dalam pembuatan Risalah lelang baik dalam lelang secara konvensional maupun dengan pelaksanaan lelang melalui media internet atau $e$-auction tetap dibuat oleh Pejabat Lelang.

3. Pejabat umum yang membuat akta tersebut harus pejabat yang mempunyai wewenang untuk membuat akta itu sesuai dengan wilayah kerjanya.

Berdasarkan ketentuan dalam Pasal 1 angka 14 Peraturan Menteri Keuangan Nomor 27/PMK.06/2016 (Berita Negara Republik Indonesia Tahun 2016 Nomor 270) menyatakan bahwa Pejabat Lelang adalah orang yang berdasarkan peraturan perundang-undangan diberi wewenang khusus untuk melaksanakan penjualan barang secara lelang". 32

Artinya "Pejabat Lelang" atau "Juru Lelang" adalah orang yang diberi "wewenng khusus" oleh Menteri Keuangan untuk melaksanakan "penjualan barang secara lelang" berdasarkan "peraturan perundang-undangan". ${ }^{33}$ Pejabat Lelang terbagi menjadi 2 (dua) golongan sebagai berikut (a) Pejabat Lelang atau Juru Lelang Kelas I yang berwenang untuk melaksanakan Lelang Eksekusi, Lelang Noneksekusi Wajib, dan Lelang Noneksekusi Sukarela. (b) Pejabat Lelang atau Juru

29 Penjelasan Pasal 1 angka 35 Peraturan Menteri Keuangan Nomor 27/PMK.06/2016 tentang Petunjuk Pelaksanaan Lelang.

30 Penjelasan Pasal 1a Vendu Reglement tentang Peraturan Lelang.

31 Penjelasan Pasal 35 Vendu Reglement tentang Peraturan Lelang.

32 Pasal 1 angka 14 Peraturan Menteri Keuangan Nomor 27/PMK.06/2016 tentang Petunjuk Pelaksanaan Lelang

33 Rachmadi Usman, Hukum Lelang, h. 34 
Lelang Kelas II yang berwenang melaksanakan Lelang Noneksekusi Sukarela.

Dengan demikian, menurut penulis Risalah Lelang melalui media internet tersebut telah memenuhi unsur-unsur yang terdapat dalam Pasal 1868, maka Risalah Lelang dalam pelaksanaan lelang melalui media internet ini dapat dikategorikan sebagai akta otentik dan dapat digunakan sebagai alat bukti yang sempurna. Akan tetapi permasalahan dalam hal pembacaan Risalah Lelang yang tidak dibacakan dan hanya ditayangkan pada aplikasi lelang sebagaimana tercatum dalam Pasal 13 ayat (1) Peraturan Menteri Keuangan Nomor 90/PMK.06/2016 yang tidak sesuai dengan ketentuan dalam Pasal 37 Vendu Reglement yang menyatakan bahwa Risalah Lelang harus dibacakan, maka dalam menyelesaikan permasalahan tersebut harus menggunakan asas Lex Specialis Derogat Legi Generalis yang menyatakan bahwa Peraturan perundang-undangan yang khusus mengesampingkan peraturan perundang-undangan yang umum. Bahwa dengan menggunakan asas tersebut maka pembacaan Risalah Lelang boleh tidak dilakukan karena adanya peraturan Menteri Keuangan Nomor 90/PMK.06/2016 tentang Pedoman Pelaksanaan Lelang Dengan Penawaran Secara Tertulis Tanpa Kehadiran Peserta Lelang Melalui Internet yang mengaturnya demikian.

Dengan adanya hal tersebut diatas, maka Risalah Lelang tetap merupakan akta otentik sepanjang tidak ada yang melakukan gugatan dikemudian hari. Apabila para pihak melakukan gugatan terhadap Risalah Lelang tersebut dan dapat dibuktikan tentang ketidakbenarannya maka Risalah Lelang dapat dibatalkan. Apabila terdapat kasus mengenai penyangkalan terhadap Risalah Lelang maka seharusnya apa yang disangkalkan harus dibuktikan, apakah terdapat hal-hal yang tidak sesuai dengan prosedur yang ditentukan dalam ketentuan peraturan perundang-undangan, termasuk juga harus dapat membuktikan terdapat pelanggaran terhadap aspek lahiriah, aspek formil, maupun aspek materiil dari Risalah Lelang tersebut. Beban pembuktian mengenai apa yang disangkalkan tersebut, dibebankan kepada pihak yang menyangkal..$^{34}$

Apabila tidak mampu membuktikan ketidakbenaran tersebut, maka akta tersebut harus diterima oleh siapapun. Peringkaran atau penyangkalan harus dilakukan dengan suatu gugatan ke pengadilan. Penggugat harus dapat membuktikan bahwa ada aspek formal yang dilanggar atau tidak sesuai dalam akta yang bersangkutan. ${ }^{35}$

34 Made Oka Cahyadi Wiguna, Keautentikan Risalah Lelang Eksekusi Hak Tnggungan Sebagai Bukti Pemindahan Hak Atas Tanah, Jurnal Hukum Undiknas, Vol. 2, No. 2 Tahun 2015, h. 167

35 Lorika Cahaya Intan, Akibat Pelanggaran Oleh Notaris Terhadap Pembuatan Akta Notaris, Jurnal Cakrawala Hukum, Vol. 7, No. 2 Desember Tahun 2016, h.209 


\section{Simpulan}

Risalah Lelang melalui media internet tersebut telah memenuhi unsur-unsur yang terdapat dalam Pasal 1868, maka Risalah Lelang dalam pelaksanaan lelang melalui media internet ini dapat dikategorikan sebagai akta otentik dan dapat digunakan sebagai alat bukti yang sempurna. Akan tetapi permasalahan dalam hal pembacaan Risalah Lelang yang tidak dibacakan dan hanya ditayangkan pada aplikasi lelang sebagaimana tercatum dalam Pasal 13 ayat (1) Peraturan Menteri Keuangan Nomor 90/PMK.06/2016 yang tidak sesuai dengan ketentuan dalam Pasal 37 Vendu Reglement yang menyatakan bahwa Risalah Lelang harus dibacakan, maka dalam menyelesaikan permasalahan tersebut harus menggunakan asas Lex Specialis Derogat Legi Generalis. Bahwa dengan menggunakan asas tersebut maka pembacaan Risalah Lelang boleh tidak dilakukan karena adanya peraturan Menteri Keuangan Nomor 90/PMK.06/2016 dan Risalah Lelang tetap merupakan akta otentik sepanjang tidak ada yang melakukan gugatan dikemudian hari.

\section{Daftar Pustaka}

\section{Buku}

Adjie, Habib.Menjalin Pemikiran-Pendapat TentangKenotariatan (Kumpulan Tulisan). Bandung: Citra Aditya Bakti, 2013.

Adjie, Habib. Sanksi Perdata dan Administratif Terhadap Notaris Sebagai Pejabat Publik. Bandung: Revika Aditama, 2013.

HS, Salim. Teknik Pembuatan Akta Satu (Konsepteoritis, Kewenangan Notaris, bentuk dan Minuta Akta). Jakarta: PT. Raja Grafindo Persada, 2015.

Kie, Tan Thong. Serba Serbi Ilmu Kenotariatan. Bandung: 1987.

Marzuki, Peter Mahmud. Penelitian Hukum Edisi Revisi. Jakarta: Prenadamedia Group, 2005.

Nasution, Bahder Johan. Metode Penelitian Ilmu Hukum. Bandung: Penerbit Mandar Maju, 2008.

Puspa, Yan Pramadya. Kamus Hukum Edisi Lengkap Bahasa Indonesia Inggris. Semarang: Aneka Ilmu, 1977.

Usman, Rachmadi. Hukum Lelang. Jakarta: Sinar Grafika, 2015. 
Artikel

Cahyadi Wiguna, Made Oka. "Keautentikan Risalah Lelang Eksekusi Hak Tanggungan Sebagai Bukti Pemindahan Hak Atas Tanah”, Jurnal Hukum Undiknas. Vol. 2 No. 22015: 167

Haprabu Satya, Burhanudin Harahap, Penjualan Lelang Barang Jaminan Hak Tanggungan Menurut Prespektif Hukum Islam, Jurnal Reportorium, Vol. IV No. 1 (Januari-Juni 2017): 59

Intan, Lorika Cahaya, Akibat Pelanggaran Oleh Notaris Terhadap Pembuatan Akta Notaris, Jurnal Cakrawala Hukum, Vol. 7 No. 2 (Desember 2016): 167

Zaki, Begiyama Fahmi, Kepastian Hukum Dalam Pelelangan Objek Hak Tanggungan Secara Online, Fiat Justicia Journal of Law, Vol. 2 No. 2 (April-June 2016): 209

\section{Perundang-Undangan}

Staatsblaad Nomor 23 Tahun 1847 tentang Burgerlijk Wetboek Voor Indonesie (KUH Perdata)

Undang Nomor 19 Tahun 2016 tentang Perubahan Atas Undang-Undang Nomor 11 Tahun 2008 tentang Informasi dan Transaksi Elektronik

Vendu Reglement tentang Peraturan Lelang

Peraturan Menteri Keuangan Republik Indonesia Nomor 27/PMK.06/2016 tentang Petunjuk Pelaksanaan Lelang

Peraturan Menteri Keuangan Republik Indonesia Nomor 90/PMK.06/2016 tentang Pedoman Pelaksanaan Lelang Dengan Penawaran Secara Tertulis Tanpa Kehadiran Peserta Lelang Melalui Internet 